Tottva, Vol. 2, No. 1, January - June 2010, pp. 51.66

ISSN 0975-332X | https://doi.org/10.12726/tjp.3.3

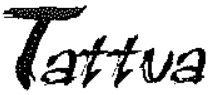

JOURNAL OF PHILOSOPHY

\title{
WHITEHEAD'S BRAIN SCIENCE OF EMOTIONS
}

\section{Thandeka Thandeka}

\section{Introduction}

Alfred North Whitehead invented a brain science of emotions using terms that obscured rather than explained his new creation. More precisely, he redefined eighteenth-and nineteenth-century philosophic terms in order to explain what they were originally designed to ignore: a felt moment, an actual occasion of felt experience; in short, a throb of emotional energy. Whitehead needed new terms to explain what he discovered. He did not have them then, but we do have now.

With the establishment of affective neuroscience and the publication of its first textbook in 1998,' we finally have access to a set of contemporary scientific terms to explain Whitehead's brain science of emotions in accessible terms. Such is the task of the present essay. Indeed it is better to begin with a brief overview of Whitehead's rationale for his new invention.

\section{Whitehead's Rationale}

Whitehead invented a brain science of emotions to resolve the "absolute contradiction" 2 he discovered in modern Western thought. He laid out the problem

1 Jaak Panksepp, Affective Neuroscience: The Foundations of Human and Animal Emotions, New York: Oxford University Press, 1998.

2 Alfred North Whitehead, Science and the Modern World, New York: The Free Press, 1967, 76. 
in three basic steps. First, scientisis described nature in mechanistic terms, characterizing fundamental elements of nalure such as gravitation mechanistically as being entirely determined by masses of things that bump into each other, Whitehead quipped, and set off confused alarms of struggle and fight like ignorant armies clashing by night. ${ }^{3}$ Second, these very same scientists, however, held "on unwavering belief that the world of men and the higher animals is composed of self-determining organisms. ${ }^{4}$ Third, since "man" is part of the natural world, he is thereby being described, at one and the same time, as lacking and yet also having free, selfdetermining agency, which is impossible.

Whitehead wanted to resolve this self-coniradictory claim. So he focused scientific, philosophic, and theological attention on that which human nature and the nafural world have in common: the psychological processes by means of which humans know ourselves as part of the natural world in which we live.

Whitehead called this common psychological ground between nature and human nature self-knowledge. More precisely, he characterized it as knowledge of a transcendent world because our bodies in themselves unify aspects of the universe. ${ }^{5}$ This knowledge, Whitehead argued, entails a feeling, an emotional intensity, which he identified in Process and Reality, as a "form of energy," "a quanlitative emotional intensity, " a vector or transmission of feeling. ${ }^{6}$

So Whitehead set out to sludy how we inherit and transform "throbs of emotional energy, clothed in specific forms provided by sensa." Whitehead's interest in these "throbs of emotional energy," however, brought him face to face with a structural difficulty: Western philosophic thought dealt exclusively in abstract notions and thereby had banished from consideration the most concrete elements of human experience - an actual occasion of felt experience. ${ }^{8}$ Thus the new problem: the "scientific field of thought," Whitehead insisted, "is now, in the twentieth century, too narrow for the concrete facls which are before it for analysis."

3 Ibid., 76, 50. Including a paraphrase of three lines cited by Whitehead of Matthew Arnold's Dover Beach.

4 lbid., 76.

5 bid., 92.

- Allred North Whitehead, Process and Reality: An Essay in Cosmology, New York: Macmillan, 1929; corrected edition, ed. David Ray Griflin and Donald W. Sherburne, New York: Free Press, 1978, 116.

7 A.N. Whiteheod, Process and Reality, 116.

$\rightarrow$ A.N. Whitehead, Process and Reality, 18.

9 lbid., 66 
To this end, Whitehead invented new meanings for familiar terms in order to develop his own new scientific, psychological field of inquiry within a field that, by its original design, could not accommodate it. Accordingly, Whitehead began to describe the processes by means of which human beings know something using standard Western philosophic ferms in a nonstandard way.

Whitehead, for example, changed Francis Bacon's notion of perception - that all bodies have perception - to the notion that bodily perception means "taking account of the essential nature of things. " ${ }^{10}$ Whitehead also changed George Berkeley's insight that natural entities are the things perceived within the unity of the mind - to the notion that the things about which Berkeley is talking are prehensions. And Whitehead changed Berkeley's notion that "realization is a gathering of things into the unity of a prehension" into the notion that what Berkeley is really talking about, according to Whitehead, is "that what is thereby realized is the prehension and not the things." Moreover, Whitehead substituted the phrase "a process of prehensive unification" for Berkeley's notion of the mind."

As a result of many such redefinition of terms from the received tradition of Western thought - of which Whitehead was a severe critic, a Whiteheadian, twentiethcentury brain science of emotions emerged that relied on the revision of seventeenth, eighteenth and nineteenth-century philosophic terms. The result: a major task of Whiteheadian scholars became that of trying to figure out what Whitehead's use of terms means. This required an in depth study of the philosophic systems Whitehead amended and an attempt to understand his alteration of the meaning of the terms in these systems and whether, of course, such changes are adequate to Whitehead's own task.

The risk in this kind of scholarly, academic work, of course, is that by trying to parse the meaning of Whitehead's revision of past philosophic terms now linked to their new twentieth-century meaning, the fundamental point of Whitehead's study of "throbs of emotional energy" can become obscured. Whitehead studied feelings as constituent processes within human experiences, which have locus points within the human brain. ${ }^{12}$ His work, as such, is an account of fundamental brain processes.

I call this attention by Whitehead to neurological impulses within the brain, Whitehead's brain science of throbs of emotional energy; or more concisely, his

lbid., 69.

lbid.

1 John Cobb Jr., A Christian Natural Theology: Based on the Thoughi of Alfred North Whitehead, Lovisville, KY: Westminster John Knox Press, 2007, 6-9. 
brain science of emotions. John Cobb aptly calls if Whitehead's "philosophy of emotion. ${ }^{\prime 13}$

These two new ways of identifying Whitehead's work emphasize Whitehead's insistence that nothing is more real than a throb of emotional energy, also called here an actual occasion of experience, and an actual entity. In short, as Whitehead puts it, "no actual entity, then no reason." 14 And thus my most basic point here is that we no longer need to master the antecedent philosophic thought with which Whitehead had to contend, in order to understand Whitehead's brain science of emotions. We do not, for example, have to parse Berkeley's philosophy, Whitehead's reinterpretation of it, and the adequacy of our own assessment of Whitehead's reinterpretation of Berkeley - in order to understand Whitehead. Rather, "psychoanalysis, neurophysiology, and philosophy together are now being called upon to develop a new theory of our participation in what we know." ${ }^{15}$ Whitehead tried to develop such a paradigm using old terms in new ways. We no longer have to use Whitehead's terms to make fundamental sense of his insights.

Whitehead wanted to break the modern Western habit of constructing personal identities based on what we think while dismissing how we feel. To this end, he calls upon us today to (1) pay attention to affective shifts in human experience, (2) note the ways in which these shifts are handled emotionally as states of self-consciousness, and to (3) study these states and the pronouncements linked to them as emotional and rational expressions of a particular community's cultural identity.

A review of John B. Cobb's, analysis of Whitehead's interest in the brain moves us one step closer to the major contribution affective neuroscience can make to Whiteheadian studies today.

\section{John Cobb on the Emotional Operating Systems of the Human Brain}

John Cobb, Jr., like Alfred North Whitehead, makes the analysis of human experience foundational to human knowledge of the ultimate nature of things. Both Cobb and Whitehead argue that attempts "to understand reality or any part of it must arise from human experience. ${ }^{\prime \prime 16}$ As both Cobb and Whitehead note, the major events

\footnotetext{
Personal e-moil correspondence from John B. Cobb Jr., March 10, 2008.

A.N. Whitehead, Process and Reality, 18.19.

is Arnold Goldberg, The Prisonhouse of Psychoonalysis, Hillsdate, NJ: The Analytic Press, $1990,164$.

is John Cobb, A Christian Nolural Theology, 3.
} 
they analyze as constituent processes within human experience have locus points within the human brain. ${ }^{7}$ The human brain thus becomes a backdrop and also $a$ staging area for their scientific explorations of human experience. In short, their work includes an account of fundamental brain processes.

Cobb makes this focus on the human brain evident in his book ANatural Christian Theology: Based on the Thought of Alfred North Whitehead when analyzing his experience of looking at a green tie and wishing it were brown. Cobb uses this example not only to clarify Whitehead's point that sense experience is secondary rather than primary to human experience, but also to locate a primary reference for this analysis: the human brain. ${ }^{18}$ And thus Cobb begins: "Suppose I am looking at a green tie and wishing it were brown." He then analyzes the "ingredients in this experience." He talks about the molecules in the tie; how the train of light coming from them strikes his eye; how the light activates certain cells that impact on the occipital lobe of the brain.

In his book The Structure of Christian Experience, Cobb expands upon this example, noting, "These nerve impulses activote selected cells in this part of the brain." This process, Cobb argues, "is not one of the unconscious dimensions of human experience but of external and bodily events. At this point, however, the chain of bodily events is at an end, and we must consider the relation of the numerous cellular events in the brain to our conscious visual experience. The chasm between these is a vast one. ${ }^{\prime 20}$ Attention to brain functions, Cobb argues here, is not enough. The chasm between the human brain and conscious human perception must be explored.

Cobb goes on to make a similar point with regard to the first stages of thought. Conscious judgments and unconscious thoughts, Cobb concludes, are not the same as the brain functions that make them possible. Cobb stales this core claim about the human brain emphatically: "I do not regard the unconscious as identical with the brain or any other entity subject to direct investigation by the physiologist.... The physicist today understands the whole world as made up of entities that can affect his senses only in very indirect ways...." Our attention, Cobb concludes, must turn to an analysis of "continuities within consciousness ... to be found within a process ... a succession of experiences in which continuity is established

\footnotetext{
a Ibid., 6-9.

18 Ibid., 5.9.

* John Cobb, Jr. The Structure of Christion Existence, New York: The Seabury Press, 1979, 28.

a lbid.
} 
by reenactment rather than by static identity. ${ }^{21}$ Clearly, we must pay atlention to these continuities within consciousness.

As Cobb notes, his analysis of human experience entails several Whiteheadian assumptions. They include: (1) human experience is a process; (2) this experience through time is composed of atomic units; (3) this "process as a whole is the succession of these atomic units;" (4) these units are "the individual occasions of human experience;" (5) each "occasion of human experience is human existence at a moment;" (6) many of these occasions of experience ore not limited to human existence; (7) the "concept of occasion of experience enables us to see what is common to the human soul and all other entities whatsoever."22 For Cobb, the distinction between humans and other entities entails the ongoing process in human existence of "the rationalization of reflective consciousness. ${ }^{\text {"23 }}$

Cobb uses the example of looking at a green tie not only to clarify Whitehead's point that sense experience is secondary rather than primary to human experience, but also to locate a primary but not exclusive reference for this analysis: the human brain. ${ }^{24}$ As Cobb goes on to demonstrate using his tie example, attention must also be paid to human mentality as feelings that have emerged within him not prompted by immediate sensate data. There are, as Cobb notes, "propositional feelings" arising in imaginative thought and thus pertaining to the "mental pole" of an occosion of experience. Such feelings, as Cobb notes, pertain to his thoughts that actively contrast a possible brown tie with the green tie he presently perceives. Moreover, Cobb suggests, all of the various types of feelings from both the mental and physical poles are accompanied by an "emotional tone," which Whitehead colled the "subjective forms" of the "prehensions that are the experiences of the entities in question. ${ }^{25}$

Cobb uses insights from disparate fields to analyze his experience of looking at the tie. As Cobb notes, "relevant knowledge about physics, physiology, and psychology" have to be taken into account to make the structure of human experience evident. From this multidisciplinary perspective, Cobb makes a convincing case that sense experience is secondary rather than the primary factor in human experience. ${ }^{26}$

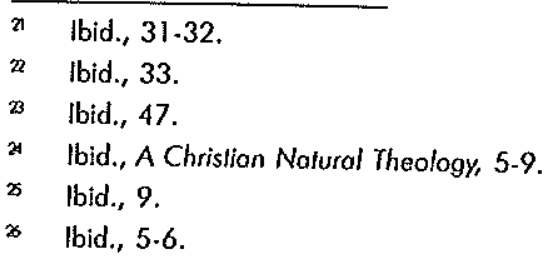


In his email message to me on 27 November 2007, Cobb highlights two key processes entailed in an adequate analysis of the multiple processes pertaining to an occasion of human experience and, more precisely, to an experience linked to the human brain: emotions and sensations. As Cobb notes in his message, which includes page citations from Process and Reality,

I said that emotion was the basic character of the subjective form of a prehension. In the categoreal scheme (p. 24) it is the first example, but there are several others: valuations, purposes, adversions, aversions, and consciousness. One discussion of the relation of physical energy to emotion is on page 116.

Cobb then reaffirms sense data as not primary to human experience. It is here that Cobb claims that he and I differ. Writes Cobb,

For most modern thought we begin with subjective experience. Often the focus is on sense experience. We... are understood to interpret this as arising beyond ourselves. For Whitehead the more concrete reality is the feeling or prehension itself. It has both a subjective form and objective data. That there are objective data is not an interpretation of the subjective form since it is co-given with the subjective form. The subjective form can, for purposes of reflection be distinguished from the prehension as a whole, but that is not its primitive form. This need not remove us from the sphere of emotion. My present feeling of discomfort is often the subjective form of discomfort of the preceding occasion. It may, of course, be the subjective form of feelings elsewhere in the body.

The main point of Whiteheadians is that the judgment that there has been a past and that there ore other people and physical objects including our bodies is not an interpretation of an experience that does not include them but a description of the most primitive form of experience. This distinguishes Whiteheadian thought from Humean, Kantian, and most other forms of modern thought.... For Whitehead the primary reality is the relation.

I agree with Cobb that sensations are not a primary factor in human experience. And in agreement with Cobb, it seemed to me that the "chasm" between cellular events in the brain and our conscious perceptions, unconscious thoughts, and conscious judgments invite further analysis and exploration.

It is here that the contemporary brain science of human emotions (affective neuroscience) might prove useful because it, too, explores this chasm and like Cobb, affirms that sense data are not foundational to human experience. This 
neuroscientific exploration also seems to offer a new basis for expanding the work Cobb has done to make Whiteheadian thought accessible and relevant to scientists and theologians today.

More precisely, I find Cobb's extraordinary altention to and interest in a "doctrine of feelings" in keeping with the cutting edge of affective neuroscience in two basic areas: (1) the relation between physical energy and emotion and (2) the affirmation of sense experience as not the primary datum of human experience. Accordingly, I draw heavily on the work of Jaak Panksepp, the founder of offective neuroscience, ${ }^{27}$ to make these two points noted above. By so doing, Cobb and I, as we continued our conversations, came to a deeper understanding and agreement about the possible role of affective neuroscience in helping to elucidate Whitehead's broin science of emotions. Here's why.

\section{Jaak Panksepp on the Emotional Operating Systems of the Human Brain}

The focal point of affective neuroscience is an energetic field that constitutes what Jaak Panksepp calls the "brain-body continuum." Here, I believe, Panksepp is consistent with Cobb and Whitehead in exploring the relation of physical energy to emotion. The exploration of this relation seems to be on entry point for what Cobb refers to as the "chasm" between brain function and human perception, conscious thoughts, and also conscious judgments. For Panksepp, the locus of this energetic field is found in the ancesfrally ancient limbic regions of the brain. A schematizing content of this subcortical energetic field is called "affect," which Panksepp describes as the primal representation of the body creating an internal physical state of awareness: $a$ "felt experience. ${ }^{28}$ Affective neuroscience shows how this affective field of body owareness (i.e., affective consciousness) is foundational for all higher cognitive, neocontical processes in the human brain (i.e., cognitive consciousness). ${ }^{29}$

This new field in contemporary neuroscience was developed by Panksepp to show how the brain works in conjunction with the body and "to clarify the interrelations between the brain and mind as expressed in the fundamental emotional processes

z Panksepp, Affective Neuroscience, viii-xii.

\$ Jook Panksepp, "On the Embodied Neural Nature of Core Emotional Affects," Journal of Consciousness Studies, 12, No. 8-10 (2005), 173.

29 Panksepp, lbid., 174. Also cited here by Panksepp, J. Parvizi ond A. Damosio, "Consciousness and the brainstem," Cognition, 79 (1-2), 2001, 135-160; D. F. Wott and D. I. Pincus "Neurat substrates of consciousness: Implications for clinical psychiatry, Textbook of Biological Psychiolry, ed. J Panksepp, Hoboken, NJ: Wiley, 2004. 
that all mammals share. ${ }^{\prime 30}$ If studies the links between brain function and human experience. By so doing, affective neuroscience enters the chasm in order to close a gap between science and the humonities. As Panksepp explains, affective neuroscience endeavors to close the gap in scientific research and academic scholarship between analyses of subjective human experiences and studies of human brain operations. ${ }^{31}$ In this way Panksepp, like Whitehead, is attempting to explain material and mental experiences within "some more comprehensive unity. ${ }^{132}$ To this end, Panksepp investigates the emotional tone linked to all human experiences, which he refers to as a pre-propositional feeling called affect.

According to Panksepp, affect is the most primitive form of human experience. Affects are "pre-propositional feelings," neural processes that create raw feelings that alert us, not through ideas, but through a felt sense of life - called affective consciousness - about how we are faring in the world, within ourselves, and with others at the somatic level of our lives. ${ }^{33}$ Affect, for Panksepp, is thus fundamentally relational. It always entails, as Whitehead would put it, a co-given. Affect is our first awareness of what is going on between physical internal states in our bodies, between our emotional systems of the brain, and between our disparate bodily sensations. Affect is the "inbetween" created when people meet. In this way, affective experiences between persons take place in an "intermediate area of experience" and as psychoanolytic theorist D. W. Winnicott observes, this kind of experience "depends for its existence on living experiences, not on inherited tendencies" ${ }^{\text {"34 }}$ because it is co-given.

There are thus three basic types of affect: (1) affect that makes us aware of the internal state of our body (e.g., hunger or fatigue); (2) affect that makes us aware of the type of emotional system that has been triggered and thus aroused; (3) affect that makes us awore of bodily sensations (e.g. tactile and visual stimulation from sources exterior to the body)..$^{35}$

As Panksepp notes, the primary categories of affective consciousness include rage, seeking (oppetite and the desire for self-gratification), anxiety, panic, fear,

so Jaok Panksepp, "The Core Emotional Systems of the Broin: The fundamental substrates of human emotions," About a Body 161; Affective Neuroscience, viii.

3. Panksepp., "The Core Emotional Systems of the Brain," 170.

3 Cobb, A Christion Nolurol Theology, 2.

3 Panksepp, "The Core Emotional Systems of the Brain," 169-170, passim.

${ }^{34}$ D. W. Winnicoll, Playing and Reality, New York: Tovislock/Roulledge, 1971, 104.110; 11.12 .

3 Panksepp, "On the Embodied Neural Noture of Core Emotional Affects," 169. 
lust, playfulness and other so-called social emolions. ${ }^{36}$ Affective psychologist and theorist Douglas F. Watt calls his work with Panksepp on identifying these cafegories, "a basic taxonomy of emofion. "37 As Kant posited pure mental categories of the mind, affective neuroscience, so it seems to me, posits pure affective categories of the body. Affect, in this way, can be thought of as a kind of volume knob of the brain's communication system to the body. It makes the signals louder and more forceful or so remote that they do not register as a displayed muscle movement, anatomical twitch, jerk, facial shift of expression, or any bodily movement of hands, feet or other part of the body used as affective gesture.

As neurologist Antonio Damasio notes, these pervasive affective stotes give our lives and thoughts definition and color. ${ }^{38}$ This coloring, Damasio emphasizes, is not the same as our foreground emotions such as an immediate fear, sorrow, joy, or flash of anger. These background feelings are the tonality of our lives, the pervasive dispositions of our being, the way in which we feel everything and express it because we salurate what we know, what we do, what we say, and how we think with what we feel.

Affective neuroscience thus seems to affirm Cobb's claim regarding a non-sensate reference for the non-sensate impressions made on the experiencing subject. Consider Cobb's analysis of his perception of the green tie again. When Cobb notes that "the seeing of the green tie ... originates in a complex and indirect process in which the molecules in the tie make an impression on the experiencing subject [this] experiencing subject most immediately experiences the events in the brain, but these relay to the subject the events in the eye that in furn point beyond themselves to their cause. Thousands of events have occurred, each having causal efficacy for its successor. All these represent the physical impact of the world upon the occasion of experience. Whitehead calls it the "physical pole" of experience [...] which can be analyzed into "physical prehensions" or "physical feelings." ${ }^{\text {"9 }}$

Secondly, sensations do not link the body to the brain. The work of Whitehead and Cobb repeatedly makes this point. So, too, does affective neuroscience. Panksepp suggests we look to affect to discern the actual link between the brain and human consciousness.

3 Panksepp, Affective Neuroscience, 53, passim; Panksepp, "On the Embodied Neurol Noture of Core Emotional Affects, ${ }^{\prime} 162$.

3 Douglas F. Walt, "Sociol Bonds and the Noture of Empathy," Journal of Consciousness Studies, 12, No 8.10 (2005), 188-212.

* Antonio Damosio, The Feeling of What Happens: Body and Emotion in the Making of Consciousness, San Diego: Harcourt inc., 1999, 286.

3 Cobb, A Christion Natural Theology, 6. 
Affect, as already noted, links the emotional operating systems of the brain to the body's physical expectations, needs, and premonitions. Emotions, Panksepp suggests, are one of a mammal's primary instinctual systems, originally functioning to direct physical action through direct links to the motor movement of limbs, head, and torso. The gateway between the brain and the body, as Panksepp puts it, is affect. For humans, emotions have retained this functional, anatomical, affective link to immediate muscle movement.

As with Whitehead and Cobb, in Panksepp's affective neuroscientific scheme of things sense data are not foundational to human experience; nor is reason. To be sure, affective triggerings can be mediated by rational consideration as well as through dream work on alternative ways of responding behaviorally to the triggered feelings. ${ }^{40}$ Nevertheless, affects are a way in which the brain neurologically assesses the surrounding environment in order to make offective judgments and thus create links to motor movements that dictate approach or retreat, seeking, rage, fear, play, lust or other neurochemical systems constructed as physical value judgments that prompt actions by the organism in its exterior environment, its world. ${ }^{41}$

Our affective commentaries on sensations, emotions, and internal muscular and anatomical shifts, Panksepp argues, are the way we initially, consciously but nonconceptually, take note or become aware of what has just happened to our body. This awareness is indeed a state of consciousness, defined here functionally as the "bare owareness of 'something'." 42

As a neurological pafterning principle, affect's neurochemical processes and electrical impulses are thus formulaic. They can be translated by scientists into mathematical and functional relationships that express these formulae. These mathematical schemes reveal the link between "acoustic dynamics and emotional dynamics. ${ }^{143}$ In this way, such analysis seems to lift up what Cobb points out as molecular processes entailed in an occasion of experience.

Panksepp hypothesizes that if modulation of sound by music has the same molecular modulation patterns as a particular emotional operating system of the brain, then

- Ponksepp, Affective Neuroscience, 135.

4 Bjorn Merker, "The liabilities of mobility: A selection pressure for the transition of consciousness in animal evolution," Consciousness and Cognition 14 (2005), 97-98. My gratitude to Dr. Douglas Watt for colling my attention to this essay, in particular, and to the work of Merker in general.

a Ibid., 101.

- Jaok Panksepp and Günther Bernaizky, "Emotional sounds and the brain: the neuro-offective foundations of musical opprecialion," Behovioural Processes 60 (2002), 150. 
they could be akin..$^{44}$ Music and other movements that have the same rhythmic proportionalities as an affective code, so this theory goes, would spark the brain of a molecular level to fire up the processes of a particular emotion system.

To test this hypothesis, a certain kind of music was piped into the cages of baby chicks. This music made them move their heads laterally in certain rhythmic manners and, as a result, decreased their separation-distress when separated from their mothers. ${ }^{45}$

As Panksepp and his co-author Günther Bernatzky note in their essay on music and affect, music that "evokes chills, a wistful sense of loss blended with the possibility of reunion may be so well represented in the dynamics of sound that we become deeply moved." Panksepp and Bernatzky are describing the affective power of music of the molecular, generative level of human emotions. As they put it: "Such musical experiences speak to us of our profound humanness and our relatedness to other people and the rest of nature. The musical experience may communicate to us the possibility of redemption, the joy of being found and nurtured if one is lost. ${ }^{466}$ The experience thus pertains to emotional tonality, our musical chords as emotional souls.

I am struck by the kinds of terms these two scientists use to describe the results of their experiment: a sense of being lost and being reunited, feelings of joy and a sense of redemption. Panksepp and Bernatzky are describing the results of triggered opioid systems of the brain amplified by affective systems in the body. These systems have physical codes. And these physical codes are entrained and/or mimed by music and thus become rhythmic patterns that quite literally reprogram our body's emotional state by altering its affect.

In other words, music as well as dance and other physical activities (such as certain physical positions for prayer or meditation) are encoded in ways that mime the coding affective patterns between the brain and the body. These codes, when triggered in the brain, produce, "tonic effects on the body." ${ }^{47}$ We were sad but now we are happy; we felt lost but now we are found; we felt abandoned and now feel embraced and saved. When this occurs, we feel amazing grace.

Perhaps it is here, in this foundational analysis of affective human consciousness that the common ground is revealed for the modern Protestant theology founded

4 Ibid.

6 Ibid., 146.

4 Ibid., 144.

- Ibid., 150, 146.152. 
by Friedrich Schleiermacher, the natural Christian theology developed by John Cobb, Jr. based on insights from Whitehead's work, and contemporary affective neuroscience founded by Jaak Panksepp.

\section{Schleiermacher and Whitehead}

I believe that Schleiermacher and Whitehead began with the same basic set of assumptions about the world and affirmed human knowledge of the ultimate nature of things through an analysis of human feeling. So, I end my paper with a few words about Schleiermacher's insight and its link to the work of John Cobb, Jr., Whitehead, and my own work in this field, which I call affect theology.

Schleiermacher called the foundational, relational material of religious life Affekt [i.e., affect] and identified it as the product of stimulated "nerves or whatever else is the first ground and seat of motions in the human body. "48 Affekt, for Schleiermacher, thus referred to the physical, emotional systems of the human body, the ways in which the human body is neurologically stimulated. ${ }^{49}$ Without such neural sparks, Schleiermacher insisted, we cannot know anything because everything about human beings begins with a feeling, a stirred emotion that sparks affective interest, focuses attention, and becomes the object for rational deliberation and reflection. ${ }^{50}$ According to Schleiermacher, Affekt is thus the first reference in human experience for all discourse on religious experience. To talk about religious experience, which he called piety [Frömmigkeit], Schleiermacher asserted, is to talk about the ways in which human feeling -Affekt - has been organized as pious. ${ }^{51}$

Friedrich Schleiermacher, On Freedom, trons. Albert L. Blackwell, Lewiston, NY: 1992, 131.

* Gunter Scholtz, Schleiermachers Musikphilosophie, Göitingen: Vandenhoeck \& Ruprecht, 1981, 93. See olso Scholtz's book, Ethik und Hemeneutik. Schleiermochers Grundlegung der Geisteswissenschaften, Fronkfurt am Main: Suhrkamp, 1995, 217. See also my essoy, "Schleiermacher's Affekt Theology" 204-212, and my essay "Schleiermacher, Feminist and Liberation Theologies," The Cambridge Companion to Schleiermacher ed. Jacqueline Mariña, Cambridge: Combridge University Press, 2005, 287-306.

5] Friedrich Schleiermacher, Die Praktische Theologie noch den Grundsözen der Evangelischen Kirche im Zusammenhange dorgestellt. Aus Schleiermachers handschriflichem Nachlosse und nachgeschriebenen Vorlesungen, ed. J. Frerichs, in: Friedrich Schleiermachers Sämmiliche Werke, Berlin (G. Reimer) 1850, 1/13, 78, 73. Reprinfed edition from: Berlin (Walter de Gruyter), 1983. Two selections from this Schleiermacher work hove been published in English: James O. Duke/Howard Stone, Eds. Christian Caring: Selections from Practical Theology, trans. James O. Duke, Philadelphia: Fortress Press, 1988.

s) Friedrich Schleiermacher, Der Chrislliche Glaube, $7^{\text {th }}$ edn., ed. Martin Redeker (Berlin: Walter de Gruyter, 1960, 2 vols.), proposition 3.4. English transtation: The Christian Foith, Eds. H. R. Mackintosh and J. S. Stewart (Philadelphia: Fortress Press, 1976). 
Piely, Schleiermacher concluded, organizes affect. To demonstrate this point, Schleiermacher created a theological system that explained all Christian doctrines, practices, beliefs, and precepts as a study of the ways in which human feelings have been modified by faith. ${ }^{52}$ Affects, in Schleiermacher's theological system, became bedrock for faith. According to Schleiermacher, these somatic movements, which he called the human soul [Seele] ${ }^{53}$, were the emotional foundation of Christian Foith. I call Schleiermacher's theological system his "Affekt Theology," because it turned Christian theology into a study of human emotions piously expressed.

In today's terms, I call the continuation and expansion of this original work by Schleiermacher-affect theology. Affect Theology studies the human emotions and affective states that guide, direct, and prioritize religious beliefs, creedal claims, liturgical structures, religious education programs, and pastoral practices by members and leaders of a religious community. As an affective analysis of religious experience, theological reflection, and leadership practices in a religious community, affect theology functions as a complement to rational theology, defined here as the systematic study of the belief systems and doctrines of a given faith community.

Schleiermacher, after all, did not make the actual study of affect and human emotions an immediate theological topic and concern. Instead, he relegated the academic study of affect to the realm of ethics, psychology, philosophy, and aesthetics. By so doing, he eviscerated his theological explorations of their own offective base by assigning the affective foundation of his theological scheme to other academic fields and disciplines. ${ }^{54}$

As a result, Schleiermacher bequeathed a foundation-less liberal Protestant theology to the modern world, ${ }^{55}$ a world that he helped to create. ${ }^{56} \mathrm{Affect}$, as a franscultural, physical foundation for the modern theology established by Schleiermacher was

5 Thandeka, The Embodied Self: Friedrich Schleiermacher's Solution to Kant's Problem of the Empirical Sell, Albany: State University of New York Press, 1995.

53 Friedrich Schleiermacher, Über den Umfong des Begriffs der Kunst in Bezug ouf die Theorie Derselben, Anhang (Akademie-Abhandlungen) 1831/32. Friedrich Schleiermachers Sämmtliche Werke (n. 5), III/3, 181-224. Schleiermacher read the first two parts of this essay on 11 August 1831 in the plenary session of the Royal Academy of the Sciences.

54 Thandeka, "Schleiermacher's Affekt Theology," 199. Thomos Albert Howard, Protestant Theology and the Making of the Modern German University, Oxford: Oxford University Press, 2006, 197-207.

s Thandeka, "Schleiermacher's AffekI Theology, 200.

ss Terrence Tice, "Schleiermacher yesterday, today, and tomorrow," The Cambridge Companion to Schleiermacher, 307, possim. Also Karl Borth, Protestont Theology in the Nineteenth Century, New Edition, Grond Rapids, Ml: William B. Eerdmans, 2001, 411. 
lost. Modern Protestant theology bequeathed to us by Schleiermacher became affect-impaired. Affect Theology helps correct this impairment and thus joins ranks with Whiteheadian projects. Whitehead, as I have repeatedly emphasized in this essay, has played a major role in helping to retrieve this lost ground of prepropositional feeling as part of human experience. John Cobb, Jr. continues this major work and has made much of the world pay systematic attention to feelings as clues to the ultimate nature of things.

Affective neuroscience is helping this enormously important Whiteheadian project gain a central place in our lives today. As John Cobb notes, based on more than 50 years of evaluating, using, and emending the work of Whitehead, both he and Whitehead affirm that the major events they analyze as constituent processes within human experience have locus points within the human brain. ${ }^{57}$ Moreover, as Cobb suggests, all of the various types of feelings from both the mental and physical poles of experience are accompanied by an "emotional tone," which Whitehead called the "subjective forms" of the "prehensions that are the experiences of the entities in question. ${ }^{158}$ Nevertheless, as Cobb notes, there is a chasm between the human brain and conscious human perception, which must be explored.

\section{The Promise}

Can insights from affective neuroscience help fill the gap John Cobb highlights between the human brain and conscious human perception? As John Cobb noted in response to this query, the use of affective neuroscience

$[\ldots]$ is a whole new field that goes a long way to bridge the gap between the objective and the subjective and to provide the kind of information that can give life to general ideas. I like the idea of using "affect" to designate the most elemental "emotions," since the latter word connotes something that is hard to generalize to purely bodily events. I think "affect" comes close to what Whitehead means by "subjective form."

Much more work, Cobb concludes, is needed to test how well the translations from Whitehead to offective neuroscience will work. "But there can be here a genuinely helpful conversation partner." 60

And thus the promise for a new stage in Whiteheadian studies: affective neuroscience. Affective neuroscience, hopefully, can help us elucidate a major goal of Whitehead's brain science: increased self-knowledge of ourselves and of our world. 